\title{
What to make of unprofitable corporate social responsibility
}

\author{
Reagan Reese Seidler \\ Office of the Minister of Justice \& Attorney General of Saskatchewan, \\ 355 - 2405 Legislative Drive, Regina, SK, S4S 0B3, Canada \\ Email: reagan.seidler@usask.ca
}

\begin{abstract}
Decades of empirical tests have yet to confirm that corporate social responsibility is and has been a financially responsible business strategy. This paper addresses why firms may choose to adopt a CSR strategy notwithstanding its bottom line effect. It is argued that a purely rational, enlightened self-interest understanding of the CSR movement is incomplete, and rather, that the insights of prospect theory allow for a fuller account of socially responsible behaviour. Analysing the business and political climate in which CSR has emerged, the paper concludes that a boundedly-rational approach to risk is inclining businesses to adopt CSR. The paper challenges business leaders and scholars to re-examine their assumptions of how risk is incorporated into CSR strategies, as well as suggesting a new path out of the social-financial performance controversy.
\end{abstract}

Keywords: corporate social responsibility; CSR; prospect theory; corporate social performance; CSP; corporate financial performance; CFP; history; politics; political economy; unprofitable; business case; risk; movement; profit.

Reference to this paper should be made as follows: Seidler, R.R. (2016) 'What to make of unprofitable corporate social responsibility', Int. J. Corporate Strategy and Social Responsibility, Vol. 1, No. 1, pp.65-85.

Biographical notes: Reagan Reese Seidler works in the Office of the Minister of Justice \& Attorney General in Saskatchewan, Canada, providing strategic policy, communications, and research services to the minister. He holds a BA (Economics) and MA (Political Studies) from the University of Saskatchewan. His work has been published in the Saskatchewan Economics Journal and Urban Voice magazine and featured at political science conferences across Canada.

\section{Introduction}

We appear to have coalesced around the idea that the corporate social responsibility (CSR) movement has been a rational phenomenon. In explaining CSR's rise, historians generally propose variants on the 'markets for virtue' perspective (Vogel, 2005), suggesting social changes have incentivised firms to act more responsibly (Frederick, 2006; Carroll et al., 2012). The underlying premise is not that businesses have become altruists, but that they have learned to adapt to changing stakeholder demands out of selfinterest. 
The sum of CSR's operational literature says much the same. For some decades, the trend in the field has been to further refine and define the business cases for social responsibility to produce practicable, repeatable, and firm-specific knowledge (Lee, 2008). Contributions to this canon extend even into this volume (Vol. 1, No.1). Articles are both prescriptive and observational; our belief in CSR's rationality evident not only because companies seek advice on how and why to implement it, but also because CSR has been so universally embraced that we assume a business case must exist to drive it. In attempting to explain the movement itself, then, it is not that shareholder value has been replaced so much as it has been superseded by a realisation that social responsibility is good business. Likewise, rationality has not been disregarded as the theoretical basis for the movement. CSR advocates are not moral pontificators, merely promoters of an 'enlightened' self-interest.

Yet this rational explanation inevitably encounters a body on the tracks. Researchers have been investigating the relationship between corporate social performance (CSP) and corporate financial performance (CFP) since the 1970s but have yet to reach the presumably-necessary consensus that the relationship is, indeed, positive. A millennial meta-analysis of empirical studies revealed mixed results, with roughly half showing a positive correlation, many revealing non-significant or inconclusive relationships, and several showing CSR was harmful to the bottom line (Margolis and Walsh, 2003). Furthermore, as Post et al. (2002, p.28) note, this catalogue of empirical studies is subject to "serious criticisms about data reliability and completeness, time period of coverage, statistical methodology, and interpretation of results", leading them to caution that "the safest generalization from [the studies] is that the empirical evidence on this matter is somewhat unreliable and the results mixed".

The implications of this are twofold. At the firm level, it suggests CSR has not been a good business decision in some instances - at least, not one that has resulted in measurable financial benefit within a reasonable timeframe. At the macro level, where we are most concerned at the present, it suggests ascribing the CSR movement purely rational motivations fails to capture the diversity of reasons corporations have embraced it. In particular, because the theory of rational choice necessitates choosing options that maximise one's self-interest, it cannot account for those instances when the CSR decision has not been driven by consideration of the bottom line. When looking positively and observationally at the CSR movement, this is the 'unprofitability problem' that arises from rational choice.

One valid response to this problem is to continue on the current research track. Empirical and case study analysis continues to become more sophisticated. With the right set of variables, it may be possible to come to the consensus that social responsibility is and always has been financially responsible, thereby validating a strict enlightened self-interest basis for the movement. On the other hand, given pervasive and enduring uncertainty on the empirical front, I am inclined to echo Rowley and Berman (2000, p.415) who "strongly suggest that social issues researchers move away from a focus on the CSP-CFP question" and look at new avenues for further inquiry.

To be so bold, perhaps the answer is not to continually revise investigation techniques but instead to revisit our assumption that CSR is, has been, and must be rational. Although the utility-maximising principle of rational choice is normatively sound, behavioural researchers and economists are recognising that agents are frequently incapable or uninterested in following it in practice, thus making it a poor theory for describing real-world decision making. 
It is the contention of this article that by using prospect theory, the most prominent theory in the field of behavioural economics, it is possible to create a fuller and more comprehensive account of the CSR movement than allowed for by rational choice. This theory differs from rational choice primarily in its understanding of how risk affects decision making. Whereas rational choice holds that decision makers have a given risk tolerance and weigh options using expected value, prospect theory observes that agents' risk tolerance changes dramatically based on whether one's perspective is set in a 'frame of gains' or a 'frame of losses'. These frames and their associated impact on risk tolerance also affect one's desire to utility-maximise, offering a sound theoretical basis for CSR when not driven by (in this case) financial gain. At the macro level, scholars have also been making the case that these theories have an advantage in explaining major changes in institutional behaviour (Weyland, 2008). A full theoretical treatment will follow shortly. For now, suffice to say we have reasonable grounds to believe the corporate sector has been making decisions from a frame of gains for many decades now, and this has had a direct impact on their willingness to expand their accountability to stakeholders.

First, as not all CSR researchers recognise or will agree that the empirical record causes a dilemma in explaining the movement, let us first turn our attention to the precise nature of the unprofitability problem.

\section{The unprofitability problem}

It is true that if one is inclined to assert that CSR has been a financially responsible undertaking, there exist enough studies to justify the perspective. Yet it would be inappropriate to present these findings as if they have constituted the consensus among analysts in this field. A notable number of studies instead suggest a negative relationship, a combination of negative and positive relationships, no relationship, or an inconclusive relationship. The Appendix to this article presents a snapshot of the results since the movement's emergence, illustrating both the mixed nature of the results and some reservations associated with the findings.

With a sense of futility, a good many scholars today are simply concluding that the debate is unresolved with no clear agreement on the relationship [Barnett and Salomon, (2012), p.1304; Davidson and Worrell, (1990), p.7; Vermuelen, (2011), p.28]. Schreck (2011, pp.167-168) summarises decades of research by offering the sage advice that "there is no reason to assume unconditionally a positive relationship between corporate social and financial performance, as such an assumption would deny both the fact that socially irresponsible behaviour does 'pay off' in certain cases and that, in other cases, the cost of beyond-compliance behaviour is not outbalanced by future returns". This has hardly been helpful to managers looking for direction. As it comes to evaluating potential projects, the guidance the literature offers is merely that "after more than thirty years of research, we cannot clearly conclude whether a one-dollar investment in social initiatives returns more or less than one dollar in benefit to the shareholder" [Barnett, (2007), p.794]. Additional time has not resolved the controversy; Lu et al. (2014) has since confirmed through meta-analysis that the debate has yet to be concluded in this decade.

Further complicating any sense of consensus are the repeated methodological criticisms between studies. Most findings drawn before the 1980s are subject to methodological concerns serious enough to warrant asterisks beside their results. Few if 
any studies are adjusted for risk; sampling errors, including the use of too few businesses in the sample, are ubiquitous; and measures of financial performance are frequently inadequate (Aupperle et al., 1985). Moreover, the evaluations of CSP, as the independent variable, are unsophisticated. Generally, studies compared a group of firms designated as 'socially responsible' against a control group. The most common method of acquiring the list of socially responsible firms was to use a reputation index, created either by the Council of Economic Priorities (1971) or Moskowitz (1972). The obvious setback to the use of a reputation index, as indicated by the very term, is that it offers a purely subjective designation rather than an objective account of firms' CSR activities. The alternative method to specify social responsibility was content analysis, reviewing documents such as annual reports to get an indication of firms' commitment to social responsibility. This approach is not a guaranteed solution, either, as mere discussion of responsibility does not equate to responsibility in practice. The inherent inadequacy of both methods (Cochran and Wood, 1984) lends no clarity to an already complicated debate.

The methodology did improve over time, especially with the introduction of reliable CSP data by the firm Kinder, Lydenberg, and Domini (KLD) beginning in May 1991. Authors appear to have endorsed KLD data, giving it wide use and relatively little criticism. Even so, other measures of CSR performance remain, with some articles preferring to use reputational, philanthropic, or self-disclosed data [Griffin and Mahon, (1997), p.16]. Yet the tentative tranquility on this front has not halted acrimonious methodological disagreements, especially on the techniques used to measure financial performance.

In 1997, McWilliams and Siegel (1997, p.627) made a compelling case that the use of short-term fluctuations in stock price to evaluate the effect of CSR, known as the event study method, was being used carelessly, cautioning that "the lack of information regarding the validity of assumptions [in the event study method] and several research design issues in some articles raises questions about the confidence that readers can place in the conclusions drawn". They stress that not all studies properly considered confounding events like major personnel changes, litigation, restructuring, or divestures, and therefore may not properly isolate CSR as the causal variable. Three years later (McWilliams and Siegel, 2000), the pair would further criticise prevailing methodological approaches, specifically the econometric model that Waddock and Graves (1997) propose to evaluate the link between CSR and financial performance. This model, along with most studies pre-dating their publication, omits independent variables that are, in the opinion of the authors, important determinants of profitability. Interestingly, while Waddock and Graves's (1997) equation produces a positive relationship between CSR and CFP, a re-analysis with an improved selection of coefficients for the assessment invalidates these results, instead producing a statistically insignificant relationship. As the authors advise, the findings "underscore the importance of using the appropriate specification when estimating the 'return' on CSR investment" [McWilliams and Siegel, (2000), p.607].

These problems continue into the new millennium [Perrini et al., (2011), p.61; Salzmann et al., (2005), p.30]. It remains the case that the choice of performance measures for both social and financial elements leads to different correlations, depending on the measures chosen. A meta-analysis conducted by Orlitzky et al. (2003) found that various components of CSR (environmental concern vs. managerial principles and minority hiring, for example) correlate differently with financial performance; that CSR 
is more highly correlated with accounting-based measures than with market-based indicators; and that reputational indices - which we criticised earlier as overly subjective - are more highly correlated with financial performance than other, presumably more objective indicators of CSR. The increasing sophistication of techniques has not quieted the debate. Griffin and Mahon (1997, p.11) identified 80 different measures of financial performance, each claiming to be superior to the others. This has since been expanded by, for example, Galema et al. (2008), Guenster et al. (2011), and Kim and Statman (2012), who have begun using advanced measures from the discipline of finance as their CFP measure. Unsurprisingly, this approach has also been criticised for inadequately capturing all relevant indicators of a company's market value (Gregory and Whittaker, 2013).

Finally, there are theoretical criticisms that the empirical literature correlates measures of business performance, such as CSR investment and profits, without a proper theory to explain it (Guenther and Hoppe, 2014; Wood and Jones, 1995). Though stakeholder theory and other operational literature has done a good deal of work to fill this void, it is still felt by some that no theory can satisfactorily explain the connection between the two [Orlitzky et al., (2003), p.404]. It is not surprising that while all academics properly couch their conclusions in provisos, CSR researchers are inordinately likely to do so, noting that findings "hint but do not univocally demonstrate" conclusions and provide "no convincing evidence on the direction of causality" [Renneboog et al., (2008), p.1740, for example].

The lack of a uniform method to investigate the link between social and financial performance only serves to further complicate interpretation of the results. The unavoidable consequence is that this immense body of research has been too convoluted to inform the decision making of businesses. Margolis and Walsh (2003, p.278), in their meta-analysis of the literature, give voice to this concern:
"The reviewers see problems of all kinds in this research. They identify sampling problems, concerns about the reliability and validity of the CSP and CFP measures, omission of controls, opportunities to test mediating mechanisms and moderating conditions, and a need for a causal theory to link CSP and CFP. The imperfect nature of these studies makes research on the link between CSP and CFP self-perpetuating: each successive study promises a definitive conclusion, while also revealing the inevitable inadequacies of empirically tackling the question."

This leaves rational accounts of CSR in some disarray. To repeat our earlier objection, it leaves the field with two avenues for further inquiry: either continue to improve investigative techniques in the hope of proving, once and for all, that social responsibility contributes to financial performance, or acknowledge that some firms have pursued CSR for reasons not based in their bottom line and find an alternative theory to explain such behaviour. It is to the latter task we now turn our attention.

\section{Prospect theory and the response to risk}

As a brief introduction, prospect theory is a descriptive theory of behaviour that seeks to explain how agents make decisions - particularly as it regards decisions under risk. In rational, expected-utility decision making, the attractiveness of a decision with a number of potential outcomes is found by weighing the utility of each outcome by the probability 
it will be realised, and in reference to one's absolute wealth level. It is also held that rational decision makers will exhibit risk aversion (Bernoulli, 1738/1954). A typical utility function is presented as concave; a twice-differentiable function of wealth $\mathrm{U}(\mathrm{w})$ defined for $\mathrm{w}>0$ such that $\mathrm{U}^{\prime}(\mathrm{w})>0$ and $\mathrm{U}^{\prime \prime}(\mathrm{w})<0$ [see Norstad (1999) for an introduction]. As such, rational risk aversion, found in the second derivative, is a consequence of the diminishing marginal utility of wealth. In lay terms, the implication is that the more wealth one has acquired, the less meaningful additional wealth becomes.

There are also certain axioms that rational decision makers must follow - rules that, logically, follow from the rational determination to maximise one's wellbeing. Of particular importance to the present task is the axiom of 'dominance'. This rule states that if option $\mathrm{X}$ is at least as good as option $\mathrm{Y}$ in every respect, and better than option $\mathrm{Y}$ in at least one respect, rational decision makers will choose option $\mathrm{X}$.

Prospect Theory reveals that people are unlikely to follow these patterns. Firstly, agents use a status-quo reference point, mentally framing decisions as 'losses' or 'gains' from the status quo rather than looking at changes in absolute wealth. Furthermore, decision makers are observed to have an S-shaped value function, with the subjective values they attach to potential outcomes highly influenced by whether decisions are framed as 'losses' or 'gains'. Facing mathematically equivalent situations, people feel losses much more strongly than gains. The consequence of this is that decision makers are risk-seeking when in a frame of loss and risk averse when in the frame of gains. To illustrate this, Tversky and Kahneman (1981, p.454) offer a laboratory example where respondents are told to make two concurrent decisions, the first in the 'frame of gains' and the second framed as losses:

Decision 1, either:

a a certain gain of $\$ 240$

b a $25 \%$ chance to gain $\$ 1,000$ and $75 \%$ chance to gain nothing.

And concurrent decision 2, either:

c a certain loss of $\$ 750$

d a $75 \%$ chance to lose $\$ 1,000$ and $25 \%$ chance to lose nothing.

The results demonstrate the effects of framing. In decision 1, option A is selected by $84 \%$ of participants. Agents exhibit strong risk aversion, preferring a sure gain even when option B has an expected value that is roughly $4 \%$ greater. The reverse is true for decision 2 when agents are put in a frame of loss. Option D is chosen by $87 \%$ of participants, as agents become willing to take on risk to avoid a loss. Of this, this article will hone in on decision 1 in particular: the risk aversion of decision makers in the 'frame of gains'.

This finding alone is not earth-shattering, for as we discussed, rational agents are also risk averse. It becomes significant and distinct from rational choice when compared against another of Tversky and Kahneman's (1981) posed questions. Consider, once more, the decisions given above. Recalling that decisions 1 and 2 were to be made concurrently, such that an agent would realise the effects of both decisions at the same time, it is worthwhile to note the pairing of decisions between 1 and 2. Results indicate that the combination of $\mathrm{A}$ and $\mathrm{D}$ was the most popular, with $73 \%$ of respondents choosing this combination. In stark contrast, the pair of B and C was chosen by only $3 \%$ of respondents. Keeping these results in mind, consider the final choice below: 
Decision 3, either:

e a $25 \%$ chance to win $\$ 240$ and a $75 \%$ chance to lose $\$ 760$

f a $25 \%$ chance to win $\$ 250$ and a $75 \%$ chance to lose $\$ 750$.

It is clear to see that $\mathrm{E}$ is the preferable option, as it entails the opportunity for a larger win and a smaller loss. Accordingly, all participants (100\%) chose option E. Interestingly, as one notices after inspection, decision 3 is merely a repackaging of decisions 1 and 2. In fact, decision $\mathrm{E}$ is mathematically equivalent to the pairing of $\mathrm{B}$ and $\mathrm{C}$, while decision $\mathrm{F}$ is the pairing of $\mathrm{A}$ and $\mathrm{D}$. Curiously, however, when the same decision is framed in different manners, it receives different responses. While it is clear $\mathrm{E}$ is preferable to F, when viewed through the lens of 'losses' and 'gains', participants ultimately chose the outcome that is unequivocally inferior. These experiments demonstrate the significant effect framing has on decision making.

This is the basis for prospect theory's first and primary advantage over the rational choice assumptions of previous scholars: it offers an explanation for those instances of CSR when social responsibility is not the 'dominant' prospect in financial terms. Although prospect theory was developed by analysing decision making at the individual level, organisational behaviour researchers have confirmed that the patterns of decision making put forward by prospect theory are also at play in the corporate world (Fiegenbaum, 1990; Fiegenbaum and Thomas, 1988). In addition, prospect theory has been used by political scientists to overcome the failures of other analytic frameworks and explain divergences from path-dependent behaviour (Weyland, 2008). Its insights also have the potential to overcome the obstacle posed by the results of inconclusive CSP-CFP research.

The proposition of this article, upon which we will expand momentarily, is that CSR is a form of risk averse behaviour undertaken by a corporate sector making decisions in an environment of consistent and substantial gains. Given the immense growth and success of corporations by every measurable standard - profit, size, or influence - just like those in decision 3, above, businesses were willing to steer some of their resources into social and community needs if it meant keeping the peace and securing their continued prosperity.

\section{CSR as a response to uncertainty}

A number of scholars have argued that CSR has been a means of mitigating risks in the political environment that have the potential to adversely affect the conduct of business. This perspective is contextually accompanied by warnings that "the capitalist system is under siege" by groups dissatisfied with corporate America, thereby necessitating CSR to win back hearts and minds [Porter and Kramer, (2011), p.64; see also Clark, 1916; Ghent, 1902; Heald, 1957, 1970; Spector, 2008]. In its present state, the belief is most commonly known as 'social licence theory' which holds that the conduct of business requires at least the tacit permission of society to operate. In its strongest form, subscribers of this perspective argue that "corporations are social institutions, creatures of society that in effect have been chartered by society to perform certain purposes. These corporations must adopt policies and actions that are in conformity to the norms and goals of society. If not, the society that granted the charter can revoke it" [Tomer, (1994), p.128]. In this 
vein, the most common benefit ascribed to CSR is the potential to lessen government intervention [Pava and Krausz, (1995), p.149], the thought being that proactive attention to issues of potential public concern can allow corporations to address the issues in a more flexible and cost-efficient manner. Weaker forms of social licence theory share the view that CSR can be a means to avoid costly interference while generally envisioning a more pluralistic institutional environment where any number of actors might upset the interests of business. These writers state that the private sector generally "needs legitimacy because it has systematically been criticised by labour unions, environmentalists, [and] anti-globalization protestors" and therefore urge corporations to act responsibly in order to "counteract these critiques" [Hanlon, (2008), p.169]. It is their view that businesses that operate with a social licence are also subject to fewer objections from non-government actors in the civil sector, and thereby avoid any adverse effects from lobbying campaigns, protests, blockades, unflattering media exposure, or other actions (Prno and Slocombe, 2012). CSR is thus a tool for public legitimacy, political capital, or a manner to prevent interference - an "industry response to opposition" [Owen and Kemp, (2013), p.29] that allows managers to run their businesses smoothly.

The great need of business to justify itself does offer a motive behind the adoption of CSR - but do we really have reason to believe that capitalism is, indeed, 'under siege'? By every conceivable measure, corporations have done and are doing well. Moreover, in the period during which CSR has come of age, the interests of the business community have found extremely cordial consideration. Though space precludes a complete treatment of this statement, there is every reason to believe the business sector is making decisions from a 'frame of gains'.

For example, it is worth considering the two pivotal threshold moments in CSR's history when firms' interest in social responsibility accelerated: the birth of the modern movement in the early 1950s, and the beginning of CSR's widespread adoption and practice in the 1990s. These moments deserve special attention as they represent what institutional scholars would call punctuated equilibriums - times when the established order was upset and a new method of behaviour emerged. Positive analyses of the CSR movement should be able to account for the timing of these two critical junctures, offering a plausible rationale for the change in business behaviour.

To begin, why would the modern discussion on the social responsibilities of corporations begin in the 1950s? The most curious aspect of this question, it seems, is why - if Clark, Heald, Spector, Porter and Kramer, and others are correct in their assertion that CSR is a response to attacks on capitalism - the movement would not have burst forth much earlier, particularly in the 1930s. For one, at no time before or since have corporations encountered such mobilised and virulent antagonism. The Roosevelt administration shared the conviction of the public that the business sector and its leaders were to blame for the stock market crash of October 1929 and the ensuing depression [Leuchtenburg, (1963), p.35; Weiner, (1952), p.724]. New Deal policies that attacked 'high finance' and sought to redistribute wealth towards workers were directly harming the material interests of businesses, leading them to criticise the New Deal as a campaign of "reckless spending... [that] stifled private initiative and enterprise" [Weiner, (1952), p.728]. Capital stock taxes, surtaxes, and excess profit taxes were all raised to help offset the cost of new welfare programs, sowing deep resentment in the business community [Leuchtenburg, (1963), p.154]. Corporations watched with dismay as wide-ranging labour legislation encouraged collective bargaining and imposed employment standards, including a maximum workweek and overtime provisions [Bernstein, (1985), 
pp.116-145]. It was an environment of unparalleled hostility for corporate America, yet did not influence business leaders to consider shifting their attention away from their own interests to placate their critics.

Rather, counter to the theories of those authors who portray CSR as a response to antagonism, the CSR movement commenced in a nearly-utopian business climate. Pre-tax domestic non-financial corporate profits repeatedly topped $12 \%$ of national income in the 1950s and 1960s, a comparatively high benchmark against other decades (Fox, 2010). In the year Bowen (1953) published his seminal work on the social responsibilities of the businessman, the seasonally-adjusted unemployment rate averaged only $2.9 \%$ (Bureau of Labor Statistics, 2014). Corporations earned $\$ 23$ billion in profit (FRED, 2014), a marked upswing from the pre-war level of $\$ 6.3$ billion in 1939 [CEA, (1947), p.49]. Firms were also unifying into larger and often international conglomerates; in 1960, 33 of the nation's top 100 non-financial businesses operated in 10 or more industries - up from 7 in 1929 (Scott, 1985).

Domestic public policy, too, was broadly accommodating. The liberals in the Truman administration envisioned an "American capitalism... [with] virtually unlimited opportunities for growth" and were focused "not on re-slicing the economic pie but enlarging it" [Hamby, (1973), p.300]. Following further losses with the passage of right-to-work laws, in some states, and federal legislation diminishing collective bargaining powers offered under the New Deal, the labour movement was reluctantly accepting that any opportunity they once had to restructure capitalism was over [Carroll et al., (2012), pp.203-204]. Moreover, firms were benefitting from an international order increasingly receptive to foreign direct investment and laissez-faire capitalism. American foreign policy was deliberately forging major and lasting international links and facilitating the export of finance-capitalism to Europe and Asia (Panitch and Gindin, 2004). These linkages empowered corporations to set up plants, offices, and subsidiaries overseas, while at the same time opening new markets for their goods.

Capitalism was by no means under threat - quite the contrary, it was in a golden age. Public policy continued to favour liberalisation and trade, with the average US tariff rate plummeting from a World War Two-high of nearly $60 \%$ to well under $10 \%$ by the 1970 s [Pomfret, (2011), p.97]. In the period from 1955 to 1973, the unemployment rate averaged $4.8 \%$, real GDP was growing at an average of $3.4 \%$ annually, and real per capita income was increasing at $2 \%$ per year [Cornwall and Cornwall, (2001), p.22]. When the nominal GNP hit $\$ 1$ trillion in 1971, it represented a doubling of the country's real per capita output in a time span of only 40 years [Heilbroner, (1977), p.210].

This trend did not end suddenly to coincide with the second significant genesis moment in CSR's history when, in the 1990s, its practical adoption began en masse. It is true that the economy faced significant challenges in the 1970s and early 1980s. Stagflation coupled with a "tidal wave of regulation" [Sicilia, (2004), p.202] put a strain on the optimism and viability of many businesses. Yet this slump in the business cycle was not accompanied by an abandonment of free trade policies but followed rather by "a deepening, acceleration and extension of capitalist globalization" [Panitch and Gindin, (2004), p.14]. The Reagan administration moved quickly to drop taxes and eliminate government involvement in the markets, such that many major industry players - such as airlines, telecommunication firms, and financial institutions - saw nearly complete deregulation [Galambos and Pratt, (1988), pp.241-245]. Carroll et al. (2012, pp.338-340) note how the forces of technological innovation, communications, and globalisation intertwined in the years following the fall of the Soviet Union to build a "new global 
economy... around the primacy of markets" wherein "American-style capitalism was touted around the world as the archetype of growth and expansion".

Accompanying the success of the neoliberal agenda has been the precipitous decline of organised labour, which has only augmented the relative power of corporations. Unions have been losing members since the 1950s, with increasingly steep losses since the Reagan era - and, as if to rub salt in the wound of a defeated labour movement, the consequence of a freer and more competitive labour market is that, according to Galambos and Pratt (1988, p.237), "the firm, not the union, has become the central focus of the worker's group loyalty". Perhaps not unsurprisingly, the diminished power of organised labour offered the corporate sector a generous bequest. Ellis and Smith (2007) record a number of figures suggesting corporations have done exceedingly well over the past decades at the expense of other groups. The share of income going to profits, or the return to capital, has been 'particularly' and 'unusually' high in nearly all western economies since the 1980s. This has come at the cost of workers, whose wage share is unusually low due to the active exertion of corporations' market leverage to bargain wages down. In other words, not only are corporations doing exceedingly well in absolute terms, but are also doing well relative to other civil society actors.

Such a full treatment is perhaps unnecessary; most are likely willing to accept, prima facie, that conditions facing the business community have been and continue to be favourable. Globalisation, free trade, and capitalism writ large are all in healthy condition. Viewed through the insights of prospect theory, the observation that business has good reason to be in a 'frame of gains' has significant implications for a positive interpretation of the CSR movement. Prospect theory advances the notion that decision makers in a 'frame of gains' will be risk averse, preferring certain gains to riskier, even dominant and higher-yielding alternatives. It is the view of this article that social responsibility has been exactly that - a form of risk averse behaviour from a corporate sector that has been very well positioned over the past half-century.

Furthermore, it should be noted, the tone of contemporary literature on CSR encourages a willingness to collaborate with stakeholders, rather than to view interactions as zero-sum negotiations. Today's best practices are very much an extension of prospect theory at work; the business sector's willingness to find areas of mutual gain not simply a function of profit-seeking, but arising from the risk aversion that accompanies an advantageous business climate. While rational choice dictates firms must act to maximise their self-interest and financial performance, it has been many years since scholars have discussed a strict trade-off between profit and social responsibility, or since profit alone has been suggested as the sole basis for investing in CSR. The classical cost-cutting school epitomised by Friedman (1970), in which CSR is conceptualised as an incremental cost to doing business, has now gone largely out of fashion. Shared (Maltz and Schein, 2012; Michelini and Fiorentino, 2012; Moon et al., 2011; Porter and Kramer, 2006, 2011) and blended value approaches (Emerson, 2003; Nicholls, 2009) now dominate the literature, with the business community largely taking CSR for granted and instead focusing their discussion on how to best implement it to create benefits for firms and their stakeholders. At other times, it is simply an acquiescence to outside pressure from NGOs, leaving businesses little room to select a particular strategy or to evaluate the impact on profit [Doh and Guay, 2006; Reinhardt et al., (2008), p.229]. Movement in this conceptual direction further reinforces the advantages of prospect theory over rational choice. Again, it all comes down to risk. 
With rational choice, it makes sense to cater to stakeholders so long as serving their interests is a means to an end. The present business case generally rests in risk mitigation and the potential for stakeholder engagement to enhance transparency and firm resilience (Cheng et al., 2013; Zadek, 2000). Yet modern strategies increasingly value stakeholders as principals in their own right, a problem difficult to conceptualise within rational choice. Not so with prospect theory. Here too, the explanatory validity of framing holds. Prospect theory tells us that because businesses are making decisions from a frame of gains, they are inclined to be risk averse even to the point of choosing options that do not maximise their material self-interest; rather, they see more value for themselves in picking safer options, the CSR route, than in pursuing risky (if more potentially more profitable) courses of action.

The real question is whether this risk aversion is rational (Godfrey et al., 2009) or a response stemming from bounded rationality. As we acknowledged earlier, risk aversion exists in both. The difference is this: in rational choice, risk aversion is a result of satiation. The implication would be that companies' wealth has reached such a height that they have stopped caring about earning more. Firms also become less risk averse as their wealth level rises because losses and gains mean relatively little past a certain threshold. Theory would therefore predict the largest, most successful companies would show increasing disinterest in CSR. None of this fits well with our understanding of how CSR has been conceptualised or practiced.

Prospect theory, on the other hand, acknowledges that absolute wealth level is not the basis of measurement; instead, decision makers are impacted by changes from the status quo. This keeps CSR's role in company and stakeholder wellbeing constantly relevant; it does not diminish with increasing wealth. Risk aversion occurs because companies see value in doing well and want to maintain their success, not because they have stopped caring about earnings. Promisingly, there exists some empirical evidence to indicate that prospect theory is indeed at play. While there is obviously a plethora of studies from which to choose, a number of sophisticated articles have flipped the typical CSP-CFP investigation on its head, and are instead investigating whether financial performance leads to social responsibility rather than the other way around. Notably, McGuire et al. (1988), Waddock and Graves (1997), Margolis and Walsh (2003), Orlitzky et al. (2003), Allouche and Laroche (2005), Margolis et al. (2007), and Margolis and Elfenbein (2008) all find evidence that corporate financial performance, as an independent variable, is positively and/or causally related to CSR. The implication is that financial success which theoretically puts decision makers in a frame of gains - inclines companies to engage in CSR.

These studies are further evidence that decision makers are not merely exhibiting a rational aversion to risk. Not only do the empirical studies above indicate that interest in CSR increases, rather than diminishes, as a firms become more successful, but the theoretical literature is consistent in portraying CSR as an activity that firms pursue after the more fundamental challenge of adequate profit has been addressed (Tuzzolino and Armandi, 1981; Carroll, 1991). Prospect theory, on the other hand, which holds that decision makers have a status quo reference point in mind rather than a level of absolute wealth, does not encounter this dilemma. Therefore, while not discounting the fact that some companies may opt to invest in CSR for purposes of rational risk mitigation, it remains the case that the use of Prospect Theory allows for a fuller and more compelling account of the CSR movement than rational choice alone. 


\section{Conclusions}

Relying on a strictly profit-based explanation for CSR, as the opening of this article describes, does leave one open to critique. The major challenge is that the rational foundation upon which such an argument is based would not allow corporations to engage in CSR if it was less profitable than acting less responsibly. This dilemma, or so I have argued, calls for the application of alternative theoretical perspectives.

One strong alternative lies in prospect theory, its major benefit being in its ability to explain how the favourable business conditions the corporate sector has experienced can increase firms' risk-aversion, therefore making less-than-dominant options more attractive.

CSR is therefore a form of risk averse behaviour - corporations are willingly deciding to be more socially responsible because it is more valuable to them to realise more certain, if potentially smaller profits than run the risk of losing their advantageous position by acting irresponsibly. This holds both at a macro-level when prospect theory is applied to the corporate sector as a whole and at the level of the firm, where empirical evidence suggests that financial performance often leads to increased levels of social responsibility.

Whether this argument sways figures in the academic and business communities remains to be seen, although it should raise important questions. If risk-aversion lies at the heart of businesses' interest in CSR, managers ought to have open conversations with their principals and stakeholders about their preferred level of risk tolerance, such that firms are being managed properly. Similarly, if CSR is an end to be achieved and policy makers see virtue in encouraging good corporate behaviour, our present finding would advance a counter-intuitive notion that less regulation and interference may actually further the cause of CSR.

The findings of prospect theory also have implications for CSR researchers. Most significantly, it provides a different theoretical lens to view the relationship between social and financial performance. Further empirical studies, especially those analysing the mediating and moderating factors affecting the social-financial performance link, ought to consider whether firms' investments in social responsibility are rooted in a rational desire to optimise company performance or rather a boundedly-rational inclination to become averse to risk once gains have been made. Furthermore, as the article suggests, historical and contemporary political context should not be overlooked. Corporations are achieving significant policy wins in the national and international arena; in light of this, their motivation to placate stakeholders with acts of social responsibility must be considered - is it driven by business considerations, or a prospect theory-based sense of satisfaction? One suspects the latter has greater influence than thus far appreciated.

Event studies, studying CSP rather than CFP metrics, may be one way to quantitatively analyse the problem. Specifically, one might analyse how firms that exceeded financial targets, such as quarterly earnings, consequently performed socially, in comparison to other firms which met their targets. This could involve overall returns that are either net negative or positive. Analysing firms in the red would yield debatable conclusions. Consider a hypothetical business that lost money overall, but did less poorly than expected, and was found to enhance its social performance. This could be interpreted as evidence the decision maker was in a frame of gains, perceiving the situation positively as 'better than expected' rather than a defeat. Contrarily, one could argue it is a rational response to a fall in net assets, as decision makers are expected to 
become more risk averse as their absolute wealth level drops. Drawing the right conclusion might depend on circumstance. A number of factors, such as the severity and length of the company's decline and the length of tenure of its senior management, might offer contextual hints as to whether better-than-expected losses suggest an optimistic or pessimistic outlook. However, were one to conclude it was a rational decision, this would face previously-mentioned obstacles: the tendency for CSP to follow CFP; the observation that size and financial performance are positively associated with CSP; the common theoretical belief that stakeholder engagement is a higher-level practice that companies seek after economic ends are met; and so on. Theory suggests a firmly entrenched goal, such as ex ante financials, can act as cognitive equivalents to status quo reference points in prospect theory (Heath et al., 1999), so again I repeat that a boundedly-rational perspective is more in line with our amassed knowledge of CSR.

The key, methodologically, is to find circumstances in which companies definitely find themselves in a frame of gains. Therefore, the most informative study would compare profitable companies that exceed their financial targets to a control group that merely meets them. This all but guarantees decision makers find themselves in a frame of gains. If businesses that exceed their targets enhance their CSP incrementally more than those in the control group, it would be confirmation prospect theory is at play. Furthermore, rational risk aversion could be ruled out, as rational choice predicts an increase in one's overall wealth level is associated with diminishing risk aversion.

The same could and should be done at the macro level - so far as CSP data would allow - to determine if the business community is incrementally more responsible when macroeconomic performance is better than anticipated. If stock market indices rise at a greater rate than expected, or fall less than expected, and it is observed companies enhance their social performance, it would provide evidence that the corporate sector becomes more responsible on account of boundedly-rational risk aversion.

As the international economy continues to integrate and globalise, and national governments forge further interlinkages with trade agreements, understanding precisely why the business sector acts responsibly will be fundamental to progressing the CSR agenda.

We have been looking for a way out of CSR's empirical quagmire for 40 years now. Although not a panacea, if prospect theory can bridge even some of the gap between where this debate is and where it needs to be, it's worth the time of our better minds.

\section{Acknowledgements}

The author wishes to thank Dr. Joe Garcea and the faculty at the University of Saskatchewan as well as the reviewers of this article for their feedback.

\section{References}

Allouche, J. and Laroche, P. (2005) 'A meta-analytical investigation of the relationship between corporate social and financial performance', Revue de Gestion des Ressources Humaines, June-August, Vol. 57, pp.18-41.

Aupperle, K., Carroll, A. and Hatfield, D. (1985) 'An empirical examination of the relationship between corporate social responsibility and profitability', Academy of Management Journal, Vol. 28, No. 2, pp.446-463. 
Barnett, M. (2007) 'Stakeholder influence capacity and the variability of financial returns to corporate social responsibility', Academy of Management Review, Vol. 32 No. 3, pp.794-816.

Barnett, M. and Salomon, R. (2012) 'Does it pay to be really good? Addressing the shape of the relationship between social and financial performance', Strategic Management Journal, Vol. 33, No. 11, pp.1304-1320.

Bernoulli, D. (1738/1954) 'Exposition of a new theory on the measurement of risk', Econometrica, Vol. 22, No. 1, pp.23-36.

Bernstein, I. (1985) A Caring Society: The New Deal, the Worker, and the Great Depression, Houghton Mifflin Co., Boston.

Bowen, H. (1953) Social Responsibilities of the Businessman, Harper \& Row, New York.

Bragdon, J.H. and Marlin, J.A. (1972) 'Is pollution profitable?', Risk Management, Vol. 19, No. 4, pp.9-18.

Brammer, S., Brooks, C. and Pavelin, S. (2006) 'Corporate social performance and stocks returns: UK evidence from disaggregate measures', Financial Management, Vol. 35 No. 3, pp.97-116.

Bureau of Labor Statistics (2014) Labor Force Statistics from the Current Population Survey [online] http://data.bls.gov/timeseries/LNS14000000 (accessed 30 May 2014).

Carroll, A.B. (1979) 'A three-dimensional conceptual model of corporate performance', The Academy of Management Review, Vol. 4 ,No. 4, pp. 497-505.

Carroll, A.B. (1991) 'The pyramid of corporate social responsibility: toward the moral management of organizational stakeholders', Business Horizons, Vol. 34, No. 4, pp.39-48.

Carroll, A.B. et al. (2012) Corporate Social Responsibility: The American Experience, Cambridge University Press, Cambridge, UK.

Chen, K.H. and Metcalf, R.W. (1980) 'The relationship between pollution control record and financial indicators revisited', The Accounting Review, Vol. 55, No. 1, pp.168-177.

Cheng, B., Ioannou, I. and Serafeim, G. (2013) 'Corporate social responsibility and access to finance', Strategic Management Journal, Vol. 35, No. 1, pp.1-23.

Clark, J. (1916) 'The changing basis of economic responsibility', Journal of Political Economy, Vol. 24, No. 3, pp.209-229.

Cochran, P.I. and Wood, R.A. (1984) 'Corporate social responsibility and financial performance', Academy of Management Journal, Vol. 27, No. 1, pp.42-56.

Cornwall, J. and Cornwall, W. (2001) Capitalism Development in the Twentieth Century: An Evolutionary-Keynesian Analysis, Cambridge University Press, Cambridge, UK.

Council of Economic Advisers (CEA) (1947) The Economic Report of the President, U.S. Government Printing Office [online] http://fraser.stlouisfed.org/publication/?pid=45 (accessed 28 May 2014).

Council of Economic Priorities (1971) Economic Priorities Report, Vol. 1, No. 6, pp.13-23.

Davidson, W. and Worrell, D. (1990) 'A comparison and test of the use of accounting and stock market data in relating corporate social responsibility and financial performance', Akron Business and Economic Review, Vol. 21, No. 3, pp.7-19.

Doh, J.P. and Guay, T.R. (2006) 'Corporate social responsibility, public policy, and NGO activism in Europe and the United States: an institutional-stakeholder perspective', Journal of Management Studies, Vol. 43, No. 1, pp.47-73.

Ellis, L. and Smith, K. (2007) The Global Upward Trend in the Profit Share, Working Paper No. 231: Bank for International Settlements, Basel, CH [online] http://www.bis.org/publ/ work231.htm (accessed 23 June 2014).

Emerson, J. (2003) 'The blended value proposition: integrating social and financial returns', California Management Review, Vol. 45, No. 4, pp.35-51.

Endrikat, J., Guenther, E. and Hoppe, H. (2014) 'Making sense of conflicting empirical findings: a meta-analytic review of the relationship between corporate environmental and financial performance', European Management Journal, Vol. 32, No. 5, pp.735-751. 
Federal Reserve Economic Data (FRED), Federal Reserve Bank of St. Louis (2014) Corporate Profits After Tax (without IVA and CCAdj), U.S. Department of Labor Bureau of Labor Statistics [online] http://research.stlouisfed.org/fred2/series/CP/\# (accessed 27 March 2014).

Fiegenbaum, A. (1990) 'Prospect theory and the risk-return association: an empirical examination in 85 industries', Journal of Economic Behaviour and Organization, Vol. 14, No. 2, pp.187-203.

Fiegenbaum, A. and Thomas, H. (1988) 'Attitudes toward risk and the return-risk paradox: prospect theory explanations', Academy of Management Journal, Vol. 31, No. 1, pp.85-106.

Fox, J. (2010) 'The real story behind those record corporate profits', Harvard Business Review Blog Network, Posted 24 November [online] https://hbr.org/2010/11/the-real-story-behindthose-re/ (accessed 3 February 2015).

Frederick, W.C. (2006) Corporation, Be Good! The Story of Corporate Social Responsibility, Dog Ear Publishing, Indianapolis, IN.

Freedman, M. and Jaggi, B. (1982) 'Pollution disclosures, pollution performance and economic performance', Omega, Vol. 10, No. 2, pp.167-176.

Freedman, M. and Jaggi, B. (1988) 'An analysis of the association between pollution disclosure and economic performance', Accounting, Auditing, \& Accountability Journal, Vol. 1, No. 2, pp.43-58.

Friedman, F. (1970) 'The social responsibility of business is to increase its profits', The New York Times Magazine, 13 September [online] http://www.umich.edu/ thecore/doc/Friedman.pdf (accessed 1 July 2015).

Galambos, L. and Pratt, J. (1988) The Rise of the Corporate Commonwealth, Basic Books Inc. Publishers, New York.

Galema, R., Plantinga, A. and Scholtens, B. (2008) 'The stocks at stake: return and risk in socially responsible investment', Journal of Banking \& Finance, Vol. 32, No. 12, pp.2646-2654.

Ghent, W. (1902) Our Benevolent Feudalism, MacMillan \& Co., Ltd., London, UK.

Godfrey, P., Merrill, C. and Hansen, J. (2009) 'The relationship between corporate social responsibility and shareholder value: an empirical test of the risk management hypothesis', Strategic Management Journal, Vol. 30, No. 4, pp.425-445.

Golicic, S. and Smith, C. (2013) 'A meta-analysis of environmentally sustainable supply chain management practices and firm performance', Journal of Supply Chain Management, Vol. 49, No. 2, pp.78-95.

Gregory, A. and Whitaker, J. (2013) 'Exploring the valuation of corporate social responsibility - a comparison of research methods', Journal of Business Ethics, Vol. 116, No. 1, pp.1-20.

Griffin, J. and Mahon, J. (1997) 'The corporate social performance and corporate financial performance debate', Business and Society, Vol. 36, No. 1, pp.5-31.

Guenster, N., Bauer, R., Derwall, J. and Koedijk, K. (2011) 'The economic value of corporate eco-efficiency', European Financial Management, Vol. 17, No. 4, pp.679-704.

Guenther, E. and Hoppe, H. (2014) 'Managing limited perspectives', Journal of Industrial Ecology, Vol. 18, No. 5, pp.689-707.

Hamby, A.L. (1973) Beyond the New Deal: Harry S. Truman and American Liberalism, Columbia University Press, New York.

Hanlon, G. (2008) 'Rethinking corporate social responsibility and the role of the firm - on the denial of politics', in Crane, A. et al. (Eds.): The Oxford Handbook of Corporate Social Responsibility, pp.156-172, Oxford University Press, New York.

Hassel, L., Nilsson, H. and Nyquist, S. (2005) 'The value relevance of environmental performance', European Accounting Review, Vol. 14, No. 1, pp.41-61.

Heald, M. (1957) 'Management's responsibility to society: the growth of an idea', Business History of Review, Vol. 31, No. 4, pp.375-384.

Heald, M. (1970) The Social Responsibilities of Business: Company and Community, 1900-1960, The Press of Case Western Reserve University, Cleveland and London. 
Heath, C., Larrick, R. and Wu, G. (1999) 'Goals as reference points', Cognitive Psychology, Vol. 38, No. 1, pp.79-109.

Heilbroner, R.L. (1977) The Economic Transformation of America, Harcourt Brace Jovanovich, Inc., New York.

Hillman, A. and Keim, G. (2001) 'Shareholder value, stakeholder management, and social issues: what's the bottom line?', Strategic Management Journal, Vol. 22, No. 2, pp.125-139.

Kim, Y. and Statman, M. (2012) 'Do corporations invest enough in environmental responsibility?', Journal of Business Ethics, Vol. 105, No. 1, pp.115-129.

King, A. and Lenox, M. (2001) 'Does it really pay to be green? An empirical study of firm environmental and financial performance', Journal of Industrial Ecology, Vol. 5, No. 1, pp.105-116.

Lee, M. (2008) 'A review of the theories of corporate social responsibility: its evolutionary path and the road ahead', International Journal of Management Reviews, Vol. 10, No. 1, pp.53-73.

Leuchtenburg, W. (1963) Franklin D. Roosevelt and the New Deal, Harper \& Row Publishers, New York.

Lu, W., Chau, K.W., Wang, H. and Pan, W. (2014) 'A decade's debate on the nexus between corporate social and corporate financial performance: a critical review of empirical studies 2002-2011', Journal of Cleaner Production, Vol. 79, pp.195-206.

Maltz, E. and Schein, S. (2012) 'Cultivating shared value initiatives: a three Cs approach', Journal of Corporate Citizenship, Vol. 47, pp.55-74.

Margolis, J.D. and Elfenbein, H. (2008) 'Do well by doing good? Don't count on it', Harvard Business Review, Vol. 86, No. 1, pp.19-20.

Margolis, J.D. and Walsh, J. (2003) 'Misery loves companies: social initiatives by business', Administrative Science Quarterly, Vol. 48, No. 2, pp.268-305.

Margolis, J.D., Elfenbein, H. and Walsh, J. (2007) Does it Pay to be Good? A Meta-Analysis and Redirection of Research on the Relationship Between Corporate Social and Financial Performance, Working Paper, Harvard Business School.

McGuire, J., Sundgren, A. and Schneeweis, T. (1988) 'Corporate social responsibility and firm financial performance', Academy of Management Journal, Vol. 31, No. 4, pp.854-872.

McWilliams, A. and Siegel, D. (1997) 'Event studies in management research: theoretical and empirical issues', Academy of Management Journal, Vol. 40, No. 3, pp.626-657.

McWilliams, A. and Siegel, D. (2000) 'Corporate social responsibility and financial performance: correlation or misspecification?', Strategic Management Journal, Vol. 21, No. 5, pp.603-609.

Meznar, M., Nigh, D. and Kwok, C. (1994) 'Effect of announcement of withdrawal from South Africa on stockholder wealth', Academy of Management Journal, Vol. 37, No. 6, pp.1633-1648.

Michelini, L. and Fiorentino, D. (2012) 'New business models for creating shared value', Social Responsibility Journal, Vol. 8, No. 4, pp.561-577.

Moon, H., Pare, J., Yim, S.H. and Park, N. (2011) 'An extension of Porter and Kramer's creating shared value (CSV): reorienting strategies and seeking international cooperation', Journal of International and Area Studies, Vol. 18, No. 2, pp.49-64.

Moskowitz, M. (1972) 'Choosing socially responsible stocks', Business and Society Review, Vol. 1, pp.71-75.

Nicholls, A. (2009) 'We do good things, don't we?: blended value accounting in social entrepreneurship', Accounting, Organizations and Society, Vol. 34, Nos. 6-7, pp.755-769.

Norstad, J. (1999) An Introduction to Utility Theory [online] http://www.norstad.org/finance/ util.pdf (accessed 3 February 2015).

Orlitzky, M., Rynes, S. and Schmidt, F. (2003) 'Corporate and financial performance: a meta-analysis', Organization Studies, Vol. 24, No. 3, pp.403-441.

Owen, J. and Kemp, D. (2013) 'Social license and mining: a critical perspective', Resources Policy, Vol. 38, No. 1, pp.29-35. 
Panitch, L. and Gindin, S. (2004) Global Capitalism and American Empire, The Merlin Press, Ltd., London, UK.

Pava, M. and Krausz, J. (1995) Corporate Social Responsibility and Financial Performance: The Paradox of Social Cost, Quorum Books, Westport, CT.

Perrini, F., Ruoss, A., Tencati, A. and Vurro, C. (2011) 'Deconstructing the relationship between corporate social and financial performance', Journal of Business Ethics, Vol. 102, No. 1, pp.59-76.

Pomfret, R. (2011) The Age of Equality: The Twentieth Century in Economic Perspective, Harvard University Press, Cambridge, MA.

Porter, M.E. and Kramer, M.R. (2006) 'Strategy and society: the link between competitive advantage and corporate social responsibility', Harvard Business Review, Vol. 84, No. 12, pp.78-92.

Porter, M.E. and Kramer, M.R. (2011) 'Creating shared value', Harvard Business Review, Vol. 89, Nos. $1 / 2$, pp.62-77.

Posnikoff, J. (1997) 'Disinvestment from South Africa: they did well by doing good', Contemporary Economic Policy, Vol. 15, No. 1, pp.76-86.

Post, J.E., Preston, L.E. and Sachs, S. (2002) Redefining the Corporation: Stakeholder Management and Organizational Wealth, Stanford University Press, Stanford, CA.

Prno, J. and Slocombe, D. (2012) 'Exploring the origins of social license to operate in the mining sector: perspectives from governance and sustainability theories', Resources Policy, Vol. 37, No. 3, pp.346-357.

Reinhardt, F., Stavins, R. and Vietor, R. (2008) 'Corporate social responsibility through an economic lens', Review of Environmental Economics and Policy, Vol. 2, No. 2, pp.219-239.

Renneboog, L., Ter Horst, J. and Zhang, C. (2008) 'Socially responsible investments: institutional aspects, performance, and investor behaviour', Journal of Banking \& Finance, Vol. 32, No. 9, pp.1723-1742.

Roberts, R.W. (1992) 'Determinants of corporate social responsibility disclosure: an application of stakeholder theory', Accounting, Organizations and Society, Vol. 17, No. 6, pp.595-612.

Rowley, T. and Berman, S. (2000) 'A brand new brand of corporate social performance', Business \& Society, Vol. 39, No. 4, pp.397-418.

Ruf, B.M., Muralidar, K., Brown, R., Janney, J. and Paul, K. (2001) 'An empirical investigation of the relationship between change in corporate social performance and financial performance: a stakeholder theory perspective', Journal of Business Ethics, Vol. 32, No. 2, pp.143-156.

Russo, M. and Fouts, P. (1997) 'A resource-based perspective on corporate environmental performance and profitability', The Academy of Management Journal, Vol. 40, No. 3, pp.534-559.

Salzmann, O., Ionescu-Somers, A. and Steger, U. (2005) 'The business case for corporate social responsibility: literature review and research options', European Management Journal, Vol. 23, No. 1, pp.27-36.

Schreck, P. (2011) 'Reviewing the business case for corporate social responsibility: new evidence and analysis', Journal of Business Ethics, Vol. 103, No. 2, pp.167-188.

Scott, J. (1985) Corporations, Classes and Capitalism, Hutchinson and Co. Publishers Ltd., London, UK.

Sicilia, D. (2004) 'The corporation under siege: social movements, regulation, public relations, and tort law since the Second World War', in Lipartito, K. and Sicilia, D. (Eds.): Constructing Corporate America: History, Politics, Culture, Oxford University Press, New York.

Spector, B. (2008) 'Business responsibilities in a divided world: the Cold War roots of the corporate social responsibility movement', Enterprise \& Society, Vol. 9, No. 2, pp.314-336.

Spicer, B. (1978) 'Investors, corporate social performance and information disclosure: an empirical study', The Accounting Review, Vol. 53, No. 1, pp.94-111. 
Stanwick, P. and Stanwick, S. (1998) 'The relationship between corporate social performance, and organizational size, financial performance, and environmental performance: an empirical examination', Journal of Business Ethics, Vol. 17, No. 2, pp.196-204.

Tomer, J.F. (1994) 'Social responsibility in the human firm: towards a new theory of the firm's external relationships', in Lewis, A. and Warneryd, E. (Eds.): Ethics and Economic Affairs, pp.125-147, Routledge, New York.

Tuzzolino, F. and Armandi, B. (1981) 'A need-hierarchy framework for assessing corporate social responsibility', Academy of Management Review, Vol. 6, No. 1, pp.21-28.

Tversky, A. and Kahneman, D. (1981) 'The framing of decisions and the psychology of choice', Science, New Series, Vol. 211, No. 4481, pp.453-458.

Ullmann, A. (1985) 'Data in search of a theory: a critical examination of the relationships among social performance, social disclosure, and economic performance of U.S. firms', Academy of Management Review, Vol. 10, No. 3, pp.540-557.

Van Beurden, P. and Gossling, T. (2008) 'The worth of values: a literature review on the relation between corporate social and financial performance', Journal of Business Ethics, Vol. 82, No. 2, pp.407-424.

Vance, S. (1975) 'Are socially responsible corporations good investment risks?', Management Review, Vol. 64, No. 8, pp.18-24.

Vermuelen, T. (2011) 'An innovative approach to funding CSR projects', Harvard Business Review, Vol. 89, No. 6, p.28.

Vogel, D. (2005) The Market for Virtue: The Potential and Limits of Corporate Social Responsibility, Brookings Institution Press, Washington, DC.

Waddock, S. and Graves, S. (1997) 'The corporate social performance-financial performance link', Strategic Management Journal, Vol. 18, No. 4, pp.303-319.

Weiner, J. (1952) 'The new deal and the corporation', The University of Chicago Law Review, Vol. 19, No. 4, pp.724-738.

Weyland, K. (2008) 'Toward a new theory of institutional change', World Politics, Vol. 60, No. 2, pp.281-314.

Wood, D. (1991) 'Corporate social performance revisited', The Academy of Management Review, Vol. 16, No. 4, pp.691-718.

Wood, D. and Jones, R. (1995) 'Stakeholder mismatching: a theoretical problem in empirical research on corporate social performance', The International Journal of Organizational Analysis, Vol. 3, No. 3, pp.229-267.

Wright, P. and Ferris, S. (1997) 'Agency conflict and corporate strategy: the effect of divestment on corporate value', Strategic Management Journal, Vol. 18, No. 1, pp.77-83.

Zadek, S. (2000) Doing Good and Doing Well: Making the Business Case for Corporate Citizenship, The Conference Board, New York. 


\section{Appendix}

Snapshot of financial/social performance studies throughout the CSR movement

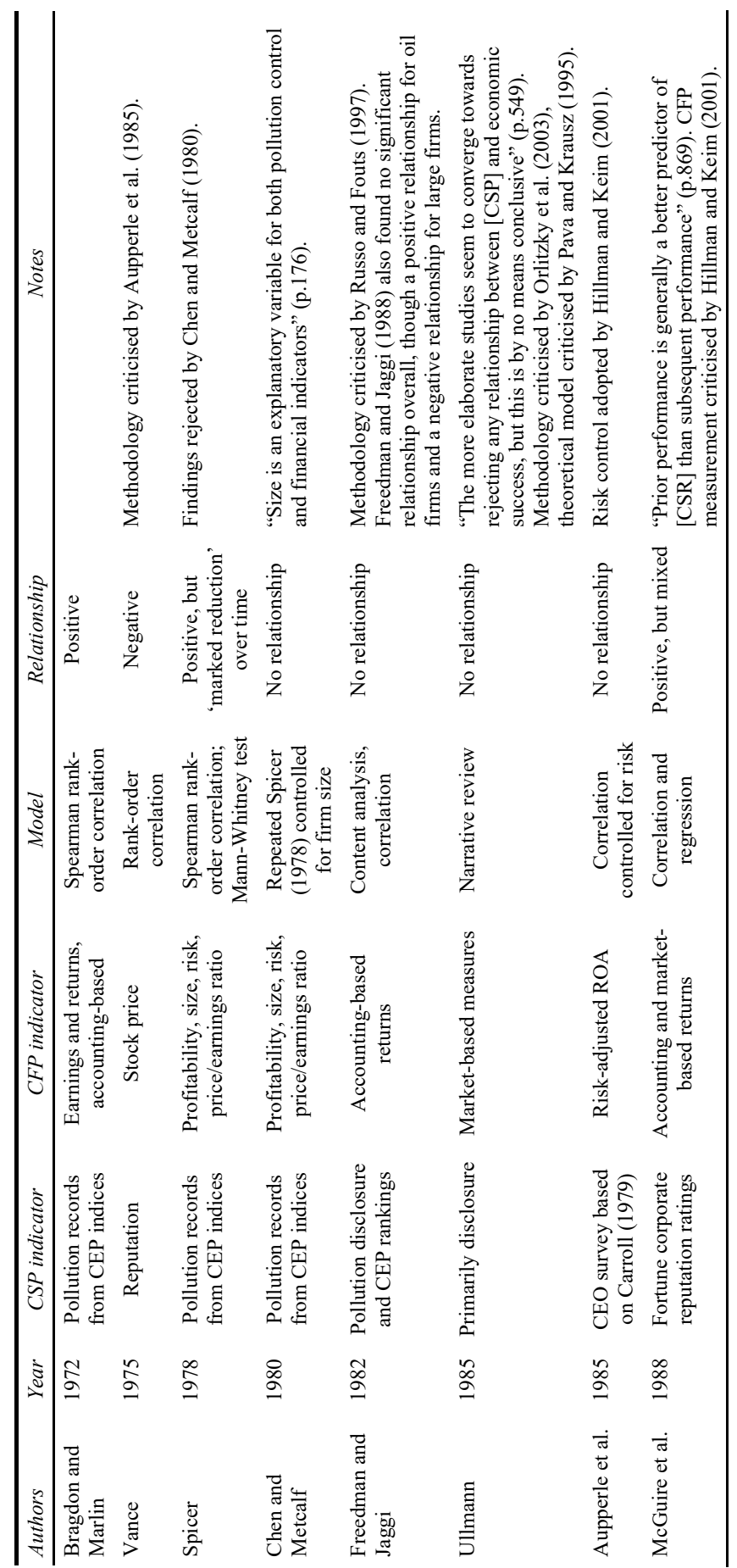


Snapshot of financial/social performance studies throughout the CSR movement (continued)




What to make of unprofitable corporate social responsibility

Snapshot of financial/social performance studies throughout the CSR movement (continued)

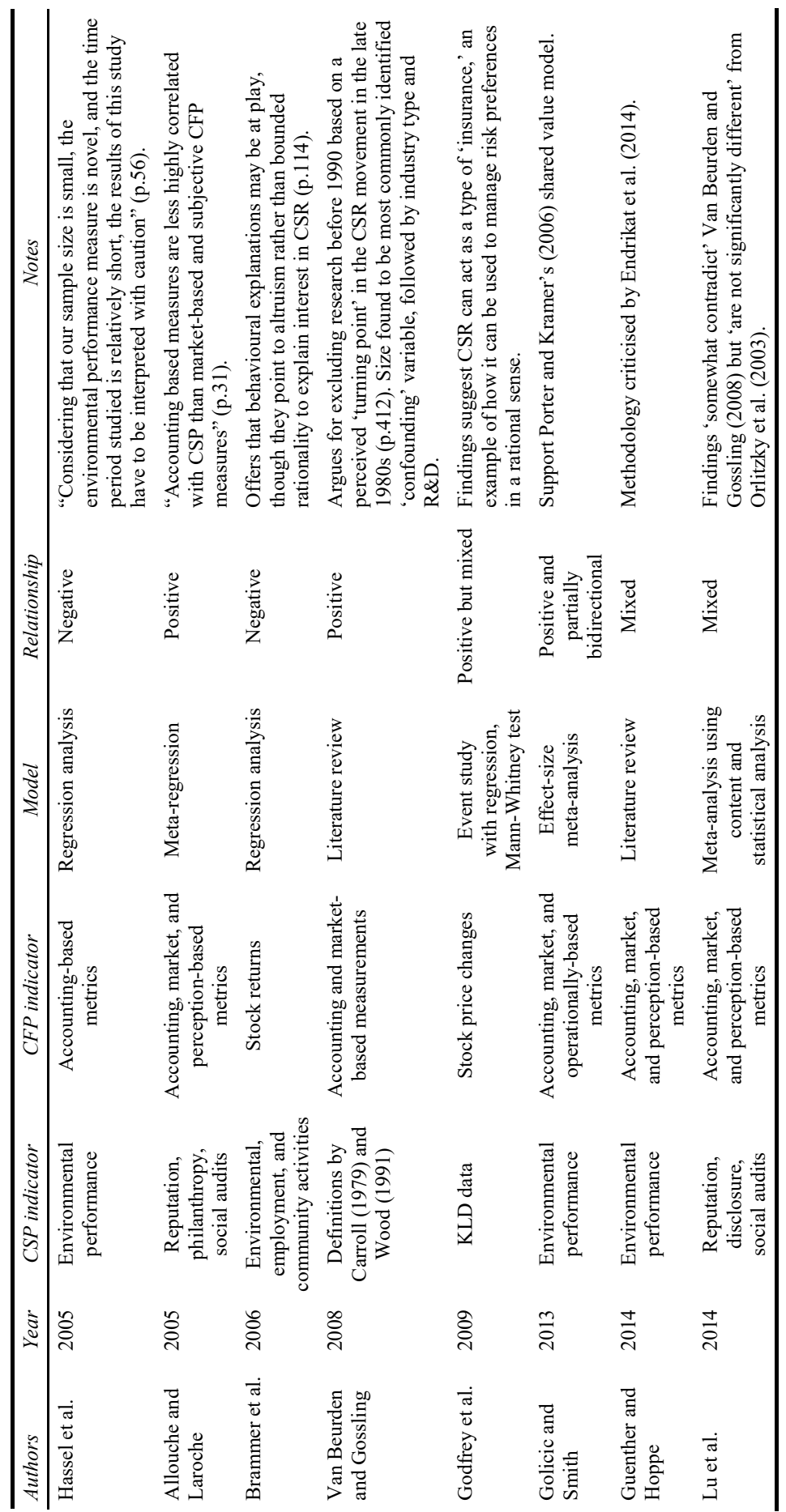

